\title{
Nuove e vecchie immagini della didattica: reale e virtuale
}

\author{
Maria Grazia Cianci \\ Daniele Calisi \\ Sara Colaceci \\ Matteo Molinari
}

Abstract

Le società contemporanee si trovano oggi a vivere una condizione mai sperimentata in precedenza. Si trovano a dover applicare e interpretare contemporaneamente aspetti materiali della vita umana da un lato, e contenuti e figure che appartengono alla dimensione virtuale.

Tema di questo scritto è riflettere intorno alle questioni del Disegno, del suo insegnamento nelle università italiane, di come esso possa svolgersi adeguatamente in una modalità di didattica a distanza e come tali tre temi si intrecciano nella situazione attuale, in cui i concetti di reale e virtuale tendono ad assumere confini sempre più dilatati e ibridati tra loro.

II Disegno e il Disegnare coinvolgono temi di un'ampia complessità. Nel gesto di disegnare si compie sempre un'esperienza di ricerca della propria segnicità. Tale articolazione del sapere è fondamentale nella formazione degli architetti. Riuscire a favorire negli studenti la scoperta di una personale segnicità e sviluppare la capacità di ognuno alla consapevolezza del segno sono le sfide e gli obiettivi da perseguire, oltre a fornire le conoscenze di base. Al centro della discussione si pone non soltanto il risultato bensì lo svolgersi del graduale processo del Disegno, ossia i molteplici atti espressivi, conoscitivi, analitici, e in generale del mettere in forma le idee.

Se tutta questa articolazione è vera, allora quale ruolo assume la didattica del Disegno nella formazione dell'architetto se svolta a distanza?

Parole chiave

disegno, didattica, didattica a distanza, linguaggio, virtuale.

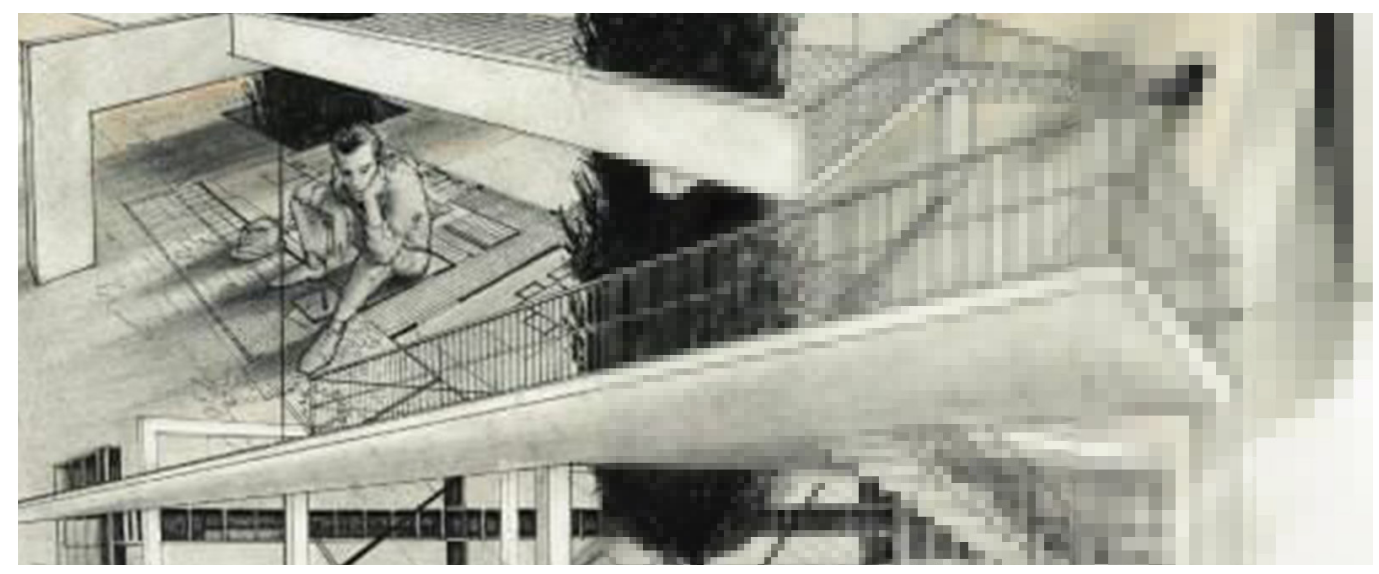




\section{Introduzione: il reale e il virtuale, oggi}

Le società contemporanee si trovano oggi a vivere una condizione mai sperimentata in precedenza. Si trovano a dover applicare e interpretare contemporaneamente aspetti materiali della vita umana da un lato, e contenuti e figure che appartengono alla dimensione virtuale. L'uomo, oggi più che mai, si è trovato catapultato da un momento all'altro, senza preavviso, in un mondo del tutto virtuale, un virtuale che a sua volta è diventato reale.

È quasi naturale quando si pensa al virtuale fare riferimento ai piani di realtà immateriale, a mondi e cose non tangibili, mondi che si oppongono alla fisicità concreta del mondo fenomenico (fig. I).

Tomás Maldonado nel suo libro [Maldonado 20I5, p. 23] entra a pieno nelle tematiche più interessanti, coinvolgenti ma allo stesso tempo più dibattute e controverse nel panorama culturale contemporaneo: quello delle tecnologie avanzate, del virtuale e degli effetti che esse possono avere sulla vita degli esseri umani e più in generale sulla cultura del nostro tempo. La simulazione della realtà offre spunti per ripensare al rapporto tra la realtà e la sua rappresentazione e tra il virtuale e la sua trasposizione, ma anche e soprattutto al rapporto tra reale e virtuale e come essi possano coesistere in un mondo nuovo, in un mondo totalmente virtuale.

Quest'anno abbiamo vissuto in un mondo illusorio, in un mondo non più parallelo ma coincidente con la realtà. In esso noi tutti, operatori attivi, siamo diventati attori in uno spazio virtuale vivendolo come se fosse reale.

Fig. I. Film del 2010 diretto da Joseph Kosinski, seguito del film Tron del 1982, regista Steven fantascienza a focalizzarsi fantascienza a focalizzars sulla realtà virtuale. Immagine tratta da: <https:// wall paperaccess.com/ tron-legacy $>$ (consultato il 20 marzo 2021)

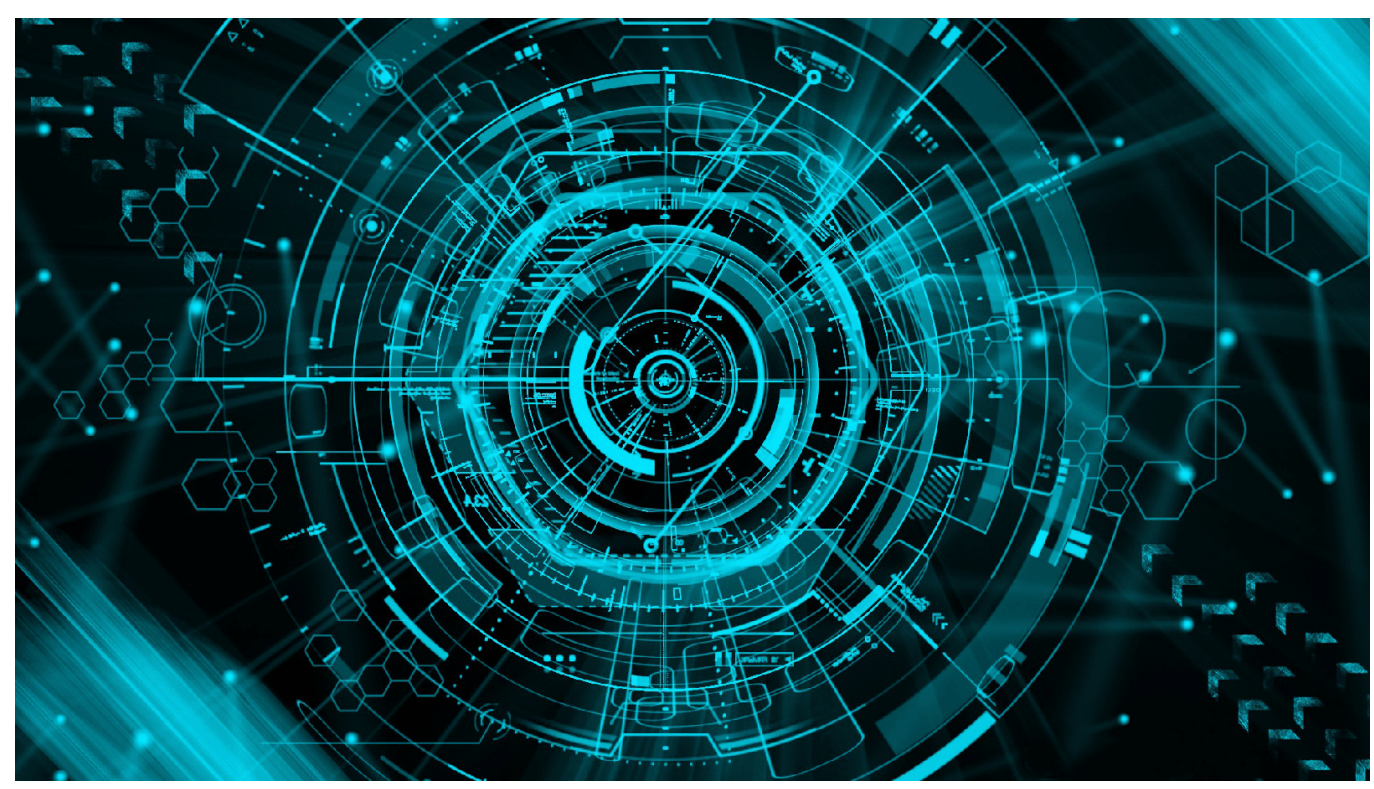

\section{Linguaggi}

Tema di questo scritto è riflettere intorno alle questioni del Disegno, del suo insegnamento nelle università italiane, di come esso possa svolgersi adeguatamente in una modalità di didattica a distanza e come tali tre temi si intrecciano nella situazione attuale, in cui i concetti di reale e virtuale tendono ad assumere confini sempre più dilatati e ibridati tra loro.

II Disegno e il Disegnare coinvolgono temi di un'ampia complessità. Nel gesto di disegnare si compie sempre un'esperienza di ricerca della propria segnicità, ovvero uno dei momenti del viaggio indispensabile alla ricerca di sé stessi.

II Disegno è presentato e narrato come espressione creativa [Giandebiaggi 2016, p. I0 I], come la forma pensiero fondamentale dell'architetto [Cervellini, Partenope 1996, p. 33], 
come un ipertesto [Quici 1995, p. 55]. Le sue funzioni sono analitica e conoscitiva, espressiva e comunicativa, esplorativa e sperimentale [Cervellini 20 I2, p. 9], di verifica e controllo [Seguì de la Riva 20 I5, p. 7], educativa verso la capacità critica [Casale, Inglese 20 I3, p. 40]. Disegnare è un lavoro lungo e impegnativo che procede per tentativi, per giustapposizioni, per ripensamenti, per sovrascritture, per affiancamenti.

Tale articolazione del sapere è fondamentale nella formazione degli architetti. Riuscire a favorire negli studenti la scoperta di una personale segnicità e sviluppare la capacità di ognuno alla consapevolezza del segno sono le sfide e gli obiettivi da perseguire, oltre a fornire le conoscenze di base. Al centro della discussione si pone non soltanto il risultato, bensì lo svolgersi del graduale processo del Disegno, ossia i molteplici atti espressivi, conoscitivi, analitici, e in generale, del mettere in forma le idee.

Se tutta questa articolazione è vera, allora quale ruolo assume la didattica del Disegno nella formazione dell'architetto se svolta a distanza? Come stimolare la visione e l'immaginazione, come promuovere la manifestazione del pensiero, come sviluppare le personali capacità espressive in un mondo reale che si fa virtuale?

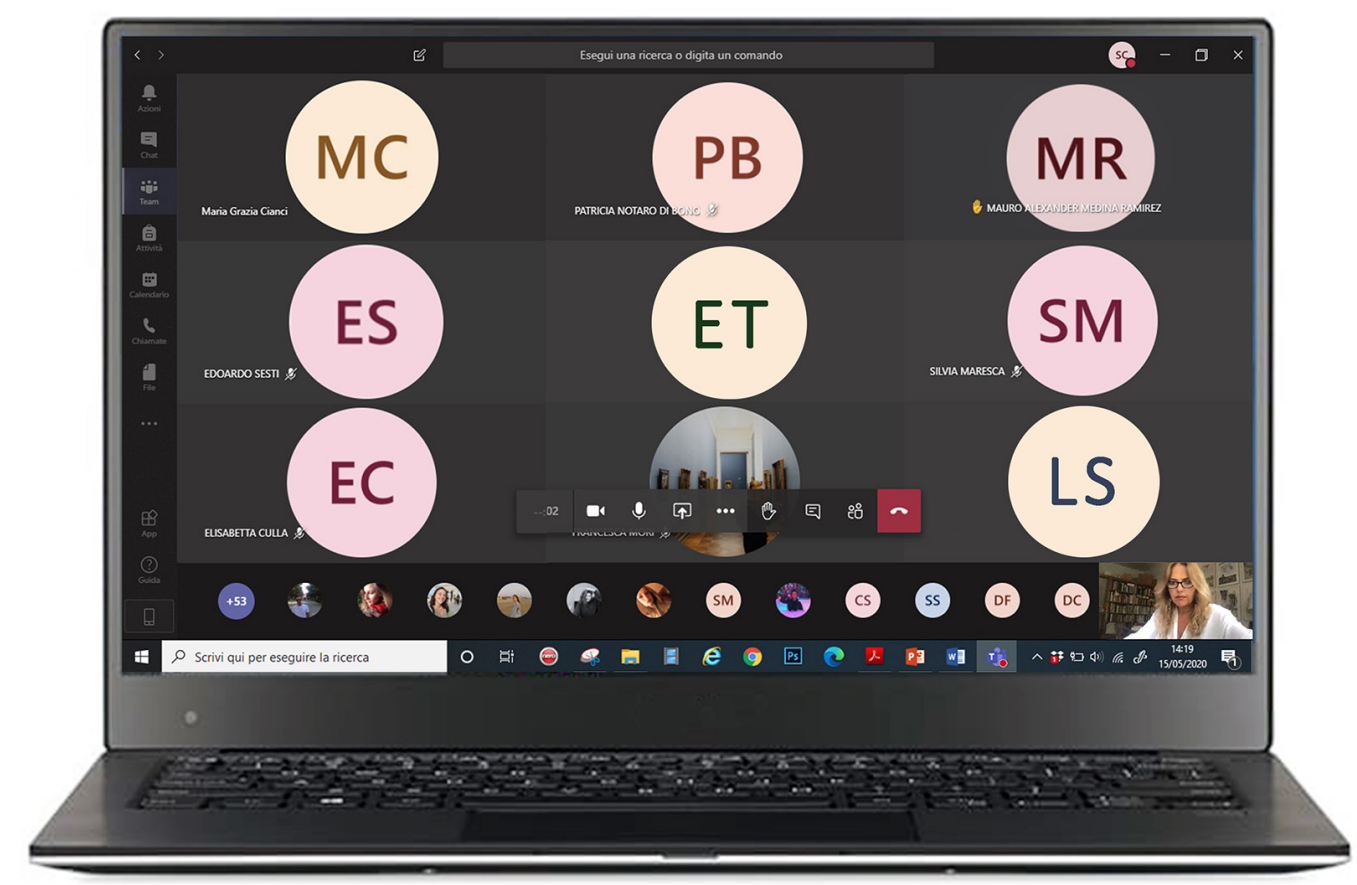

Fino a marzo 2020 l'insegnamento si compiva e si avviava attraverso manifestazioni esperienziali tangibili e concrete che, quandanche semplici e basiche, necessitavano di una fisicità: far scoprire gli strumenti, provare le tecniche, perlustrare i luoghi della città in un rapporto partecipativo tra docente e discente. Nel Disegno concorrono le proprietà tattili delle materie fisiche e delle materie architettoniche coinvolte in esso che è inammissibile escludere. Con la didattica a distanza è necessario evitare il rischio e la deriva che essa si risolva in un modello di apprendimento che la psicologia dell'educazione indica come metafora della trasmissione della conoscenza, ossia costituito dal docente (emittente) che trasferisce conoscenza al discente (ricevente) [ I ]. In tale modello la conoscenza è considerata qualcosa di predefinito, la mente è considerata un contenitore e si compie soltanto un ascolto da parte dello studente, senza una trasformazione durante il trasferimento della conoscenza. L'assenza della tangibilità e, più in generale, la mancanza delle relazioni umane che si verificano nella DAD (fig. 2) conducono al successo di un modello che favorisce l'apprendimento 
Fig. 3. Studenti che disegnano a loro tavolo, nell'aula virtuale ossia la ro abitazione, durante una lezione di didattica a distanza. individuale e che annulla quei valori di costruzione e di partecipazione, fondamentali in un percorso di formazione.

II Disegno, o meglio l'insegnamento di esso, implica un sapere e un saper fare, la dialettica e l'esercizio, la teoria e la pratica, dunque occorre evitare che sia confinato in modelli di apprendimento restrittivi che non gli appartengono e che non sono insiti nella sua natura. Per tali ragioni, nel corso di Disegno dell'Architettura si è cercato di sollecitare la dimensione operativa del Disegno. La mancanza di interazione fisica ha impedito quel fondamentale momento didattico in cui il docente 'mette la matita sul foglio' per correggere gli errori, per sperimentare le tecniche o per manifestare, semplicemente, la valenza e l'unicità del segno grafico. Tuttavia, si è cercato di sopperire tale mancanza attraverso alcune accortezze. Ad esempio, si è mantenuto il 'disegnare in aula' da parte degli studenti (fig. 3), ma anche dei docenti e degli assistenti, con lo scopo di mantenere vivo e costante il legame con la disciplina.

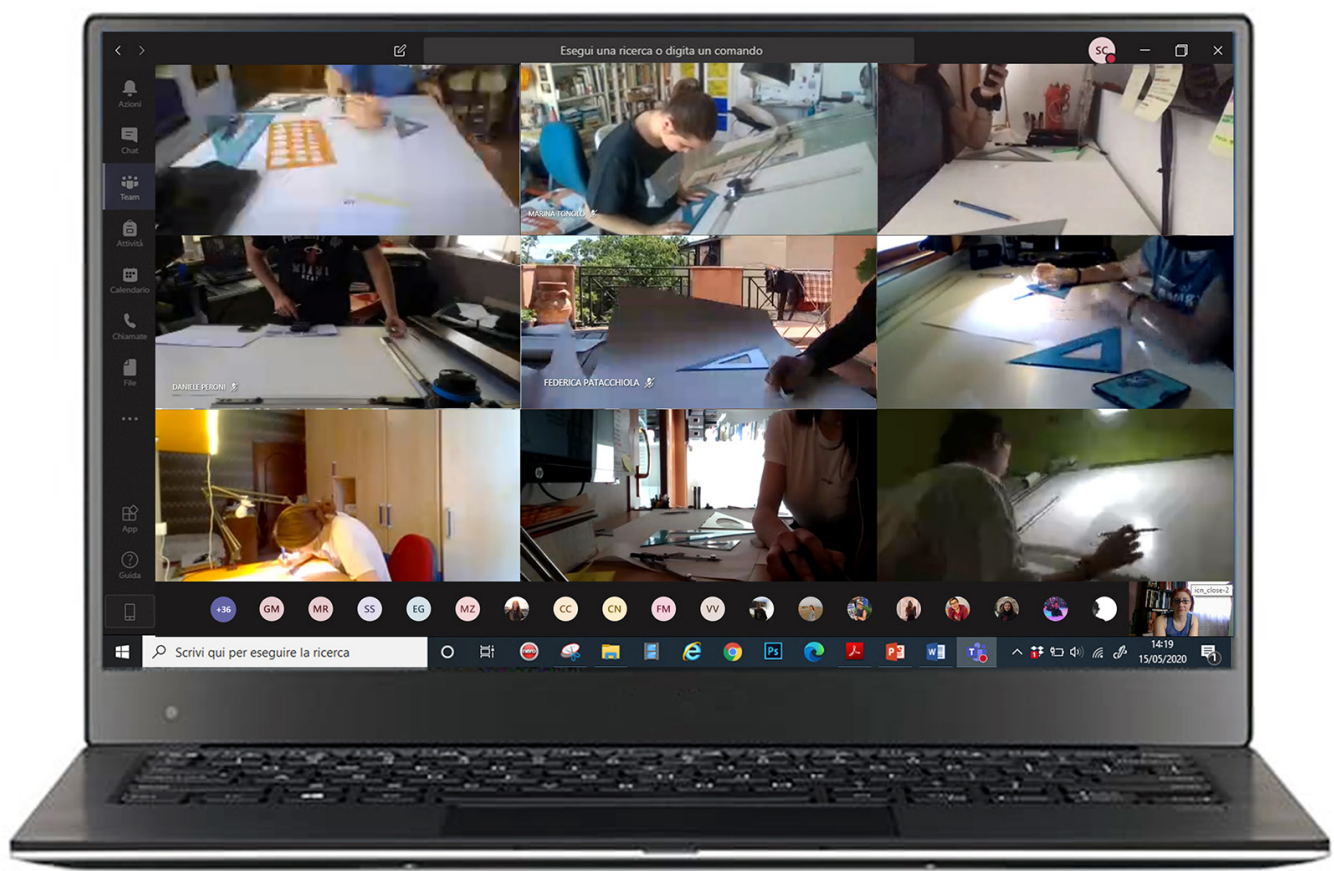

\section{Tecnologie}

Nell'ultimo anno la tecnologia e il digitale hanno assunto un nuovo ruolo nel campo della comunicazione, insegnamento e divulgazione del disegno architettonico. Se prima venivano visti come lo strumento che avrebbe portato alla fine del disegno analogico adesso si sono trasformati nell'unico mezzo attraverso il quale è possibile insegnarlo. Per secoli, il termine digit (dal latino digitus) ha indicato il dito, ma ora la sua forma aggettivale, digitale, si riferisce ai dati; questa sua trasformazione ricalca perfettamente le necessità odierne.

La virtualizzazione delle aule ha cambiato non solo il modo in cui le persone si relazionano, ma anche la percezione del tempo stesso. La società del $X X \mid$ secolo è iper-connessa, tutto può essere fatto attraverso un computer, uno smartphone, un tablet, e tutto deve essere istantaneo.

Lo stile di vita dell'uomo ha subito un'accelerazione in cui gli stessi rapporti sociali sono più facili da stabilire, ma allo stesso tempo più fragili. Questa digitalizzazione è sempre stata una parte della vita di una persona, dove la fisicità dei rapporti e la possibilità di interagire con il mondo circostante bilanciavano questa continua necessità di iper-connessione. Un 
Fig. 4. Lezione frontale durante la quale sono stati condivisi dei disegn finalizzati alla spiegazione del progetto di architettura.

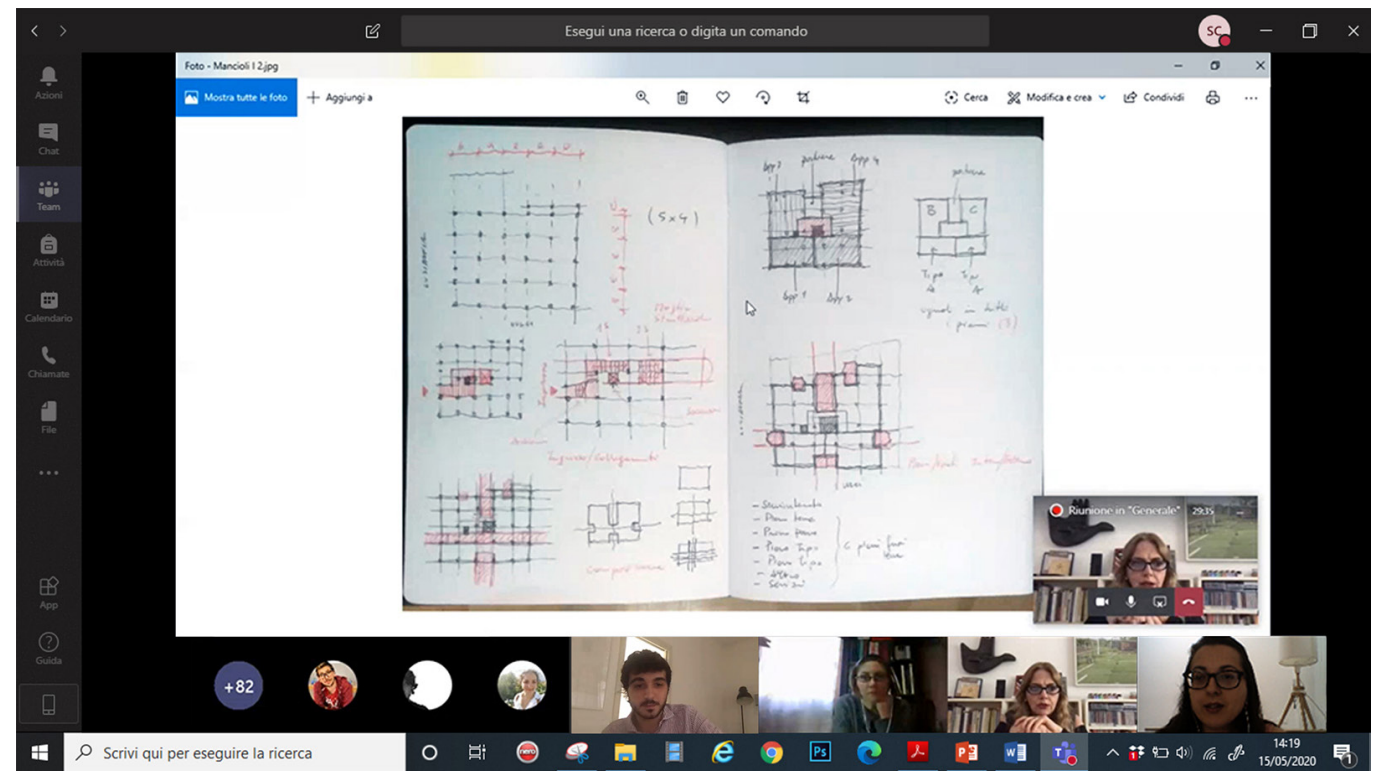

bilanciamento non perfetto, quindi, tra l'accelerazione data dal digitale e lo scorrere naturale del tempo nei rapporti umani. Nella società dell'iper-connessione e dell'iper-complessità occorre alternare velocità e lentezza, poiché l'uomo ha bisogno di entrambe.

L'insegnamento universitario ha dovuto comprendere e saper utilizzare la tecnologia in pochi mesi per riuscire a trasmettere gli stessi concetti.

L'insegnamento del Disegno dell'Architettura si basa su uno scambio non solo di concetti ma di movimenti, di tecniche che è possibile apprendere attraverso un insegnamento diretto e pratico, attraverso il quale si instaura un rapporto tra docente e studente. Per questo motivo il corso di Disegno dell'Architettura ha dovuto assimilare le piattaforme digitali per cercare di trasmettere gli stessi insegnamenti a distanza.

La tecnologia ha permesso la condivisone dei disegni in diretta durante la lezione per commentarli e per correggerli (fig. 4). Essa, inoltre, ha consentito le verifiche didattiche poiché gli

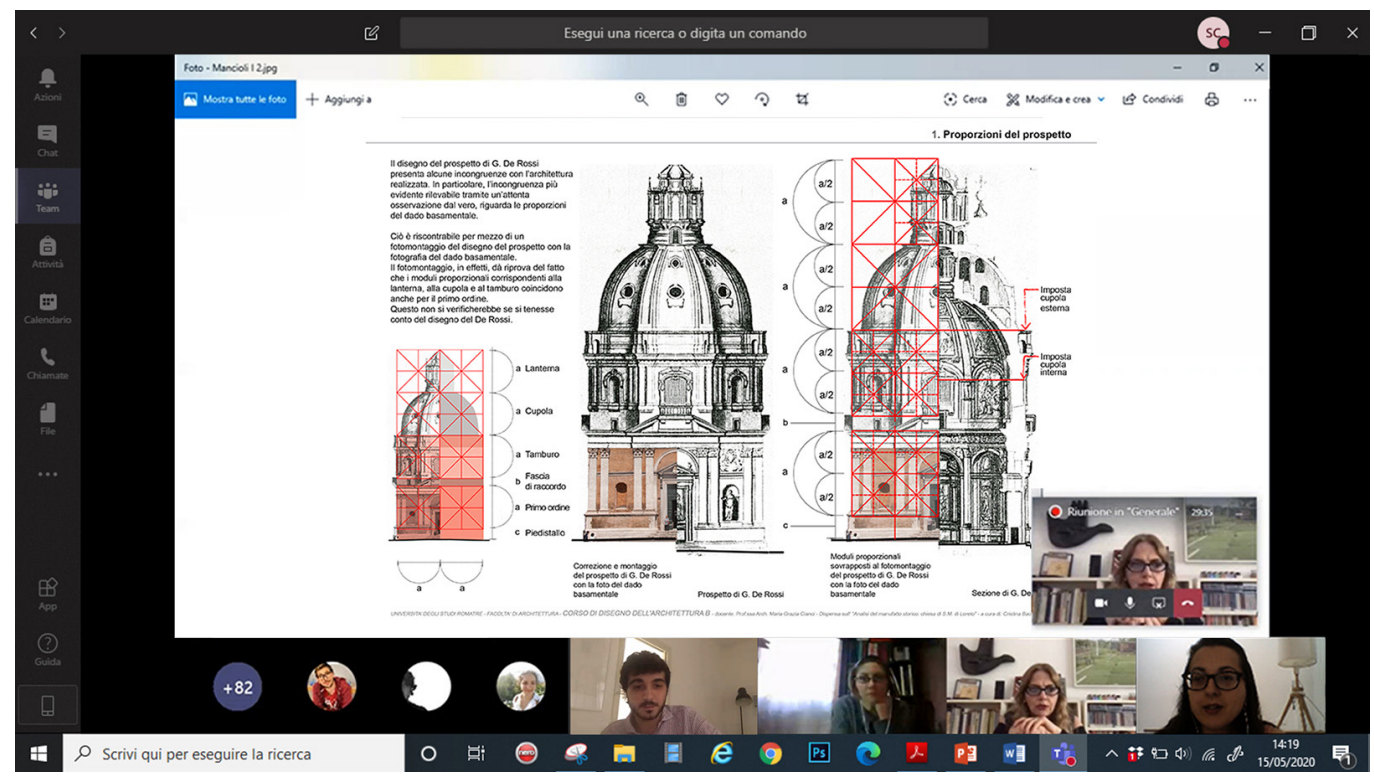


elaborati, consegnati e caricati su piattaforma, sono stati corretti successivamente dal corpo docente attraverso la tavoletta grafica.

Le tecniche di rappresentazione sono state mostrate attraverso video registrati, tipo tutorial, in cui lo studente può vedere la mano che definisce i segni, le campiture, le texture, il colore. Le piattaforme (Teams, sito elearning, blog, fb) hanno consentito di mettere in atto le lezioni frontali (figg. 5, 6), e quellinsieme di organizzazione e gestione del corso costituita da avvisi, dispense, compiti da svolgere con scadenze settimanali, oltre alla condivisione del materiale didattico.

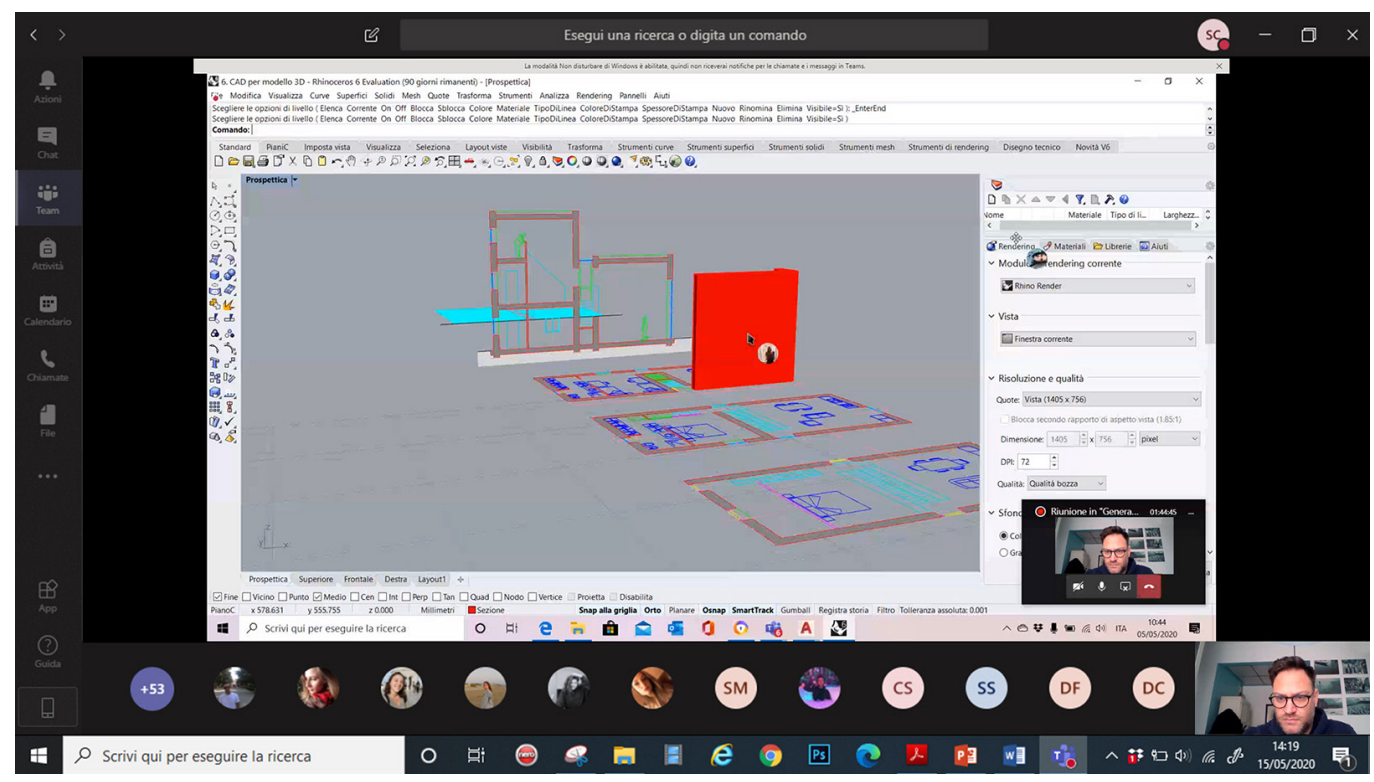

\section{Distanze: relazioni tra tempo, condivisione e connessioni}

Una sostanziale differenza tra il reale e il virtuale è la distanza sotto diverse accezioni: in termini di distanza fisica che ci divide da una meta, di distanza sociale o di distanza percettiva. Nello stesso mito della caverna di Platone la percezione delle ombre (il virtuale) è immediata per l'uomo che è ignaro non solo di cosa sia il vero, ma anche della distanza effettiva della realtà. Abbiamo dovuto imparare a escludere le distanze dalla nostra vita, obbligati a rileggere una

quotidianità consolidata fatta di distanze da percorrere per raggiungere i luoghi di lavoro, amici o parenti, di contatti sociali o fisici.

E se l'obbligo di rimanere fermi ci ha allontanato dai nostri luoghi e dalle realtà abituali, il virtuale ci ha donato infinite possibilità di connessione [Heidegger 1976, p. 28].

Tuttavia, limitarsi alla sola distanza geometrica non esaurisce la descrizione dei nostri rapporti con persone e cose in cui entrano condizionamenti culturali e ideologici legati anche alla personalità soggettiva. Heidegger, quando tratta dell'Esserci come struttura esistenziale, affronta il tema della cura, dell'essere in un contesto o in uno spazio. L'uomo ha un rapporto esclusivo con il mondo che lo abita ma allo stesso tempo se ne prende cura, se ne preoccupa e se ne interessa. Questo concetto esula dalla spazialità dimensionale ma è collegato alla situazione esistenziale relativa. Il dis-allontanamento ha permesso, nell'ultimo anno, di far scomparire le distanze fisiche, e ci ha permesso di prenderci cura delle nostre cose in modi differenti e lontani dai nostri modi d'essere abitudinali.

In questa anormalità, si è cercato di condurre un corso a distanza mantenendo i medesimi obiettivi di un corso in presenza. Sono stati conservati gli argomenti, ossia il progetto di 
Fig. 7. Extempore I sul progetto di architettur la Casa delle Stregh di Mario Ridolfi. La tavola è stata realizzat nel corso di Disegno dell'Architettura, svolto in didattica a distanza durante i mesi in

lockdown (studentessa Chiara Tucci).

Fig. 8. Extempore 2 sulla comprensione dell architettura Classica: Chiesa di Santa Maria di Loreto. La tavola è stata realizzata nel corso di Disegno dell'Architettura, svolto in didattica a distanza durante i mesi in lockdown (studentessa

Flavia Manciocchi).

Fig. 9. Extempore 2 sulla comprensione

dell'architettura classica: Ia

Chiesa di Santa Maria di

Loreto. La tavola è stata

realizzata nel corso di

Disegno dell'Architettura,

svolto in didattica a

distanza durante i mesi

in lockdown (studente

Marco Peperoni

Romano).
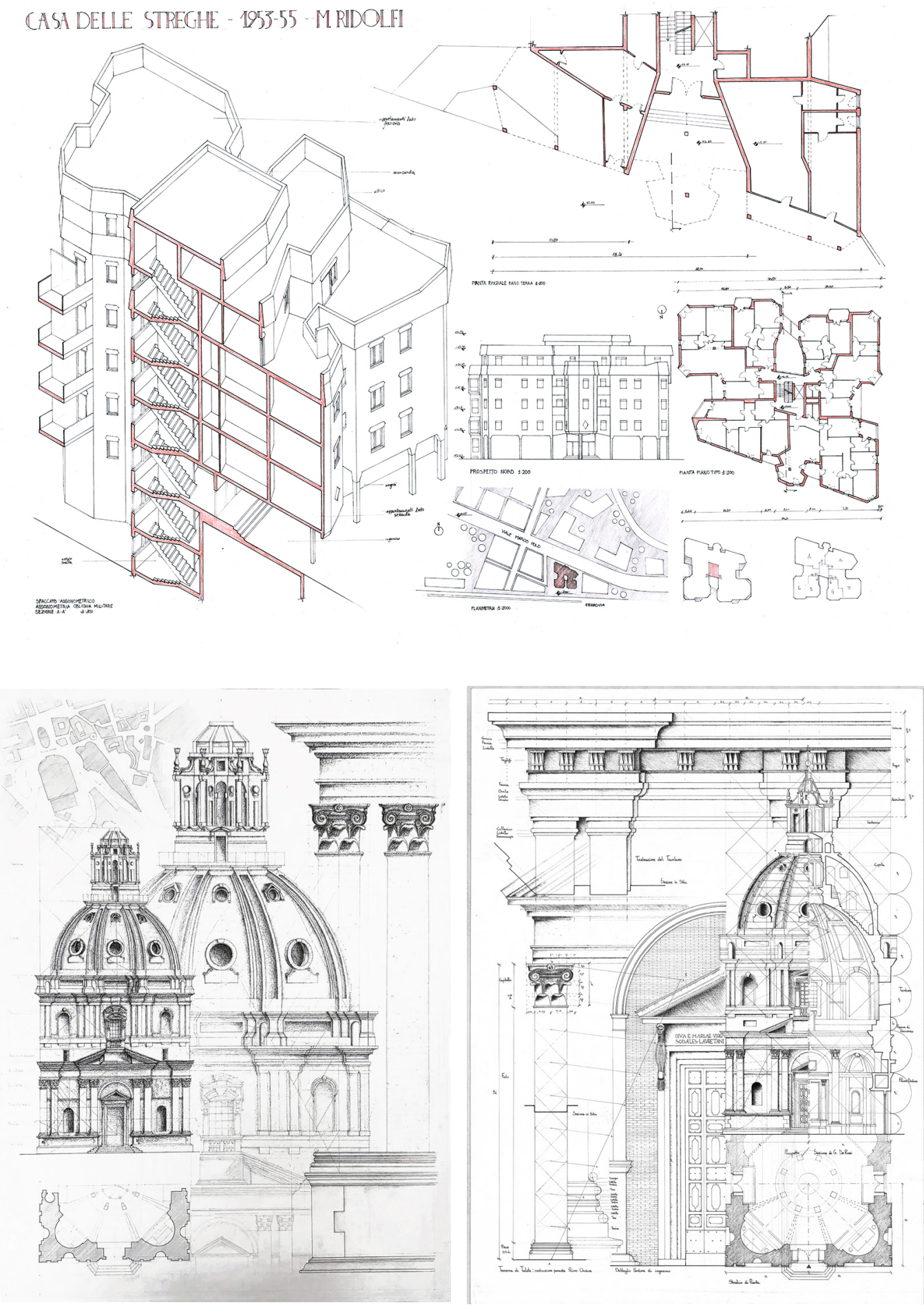
Fig. 10. Extempore 3 sul manifesto di architettura: INA Casa Tiburtino di

Mario Ridolfi. La tavola sario Ridolfi. La tavola è di Diseano dell'Arcitetdis Disegno del'Architettura, svolto in didattica a distanza durante imesi in lockdown (studentess llaria Inglisa).

Fig. I I. Extempore 3 sul manifesto di architettura: Palazzina Colombo di

Mario Ridolfi. La tavola è stata realizzata nel corso di Disegno dell'Architettura, svolto in didattica a distanza durante i mesi in lockdown (studentess Flavia Manciocchi). architettura, la comprensione dell'architettura classica, il manifesto di architettura (figg. 7-9) sviluppati con disegni analogici e rappresentazione digitale (figg. I0-I2), mentre il rilevamento (a vista e diretto) è stato rimosso. Sono state conservate le extempore, le tavole e il taccuino, al fine di fornire la medesima formazione didattica.
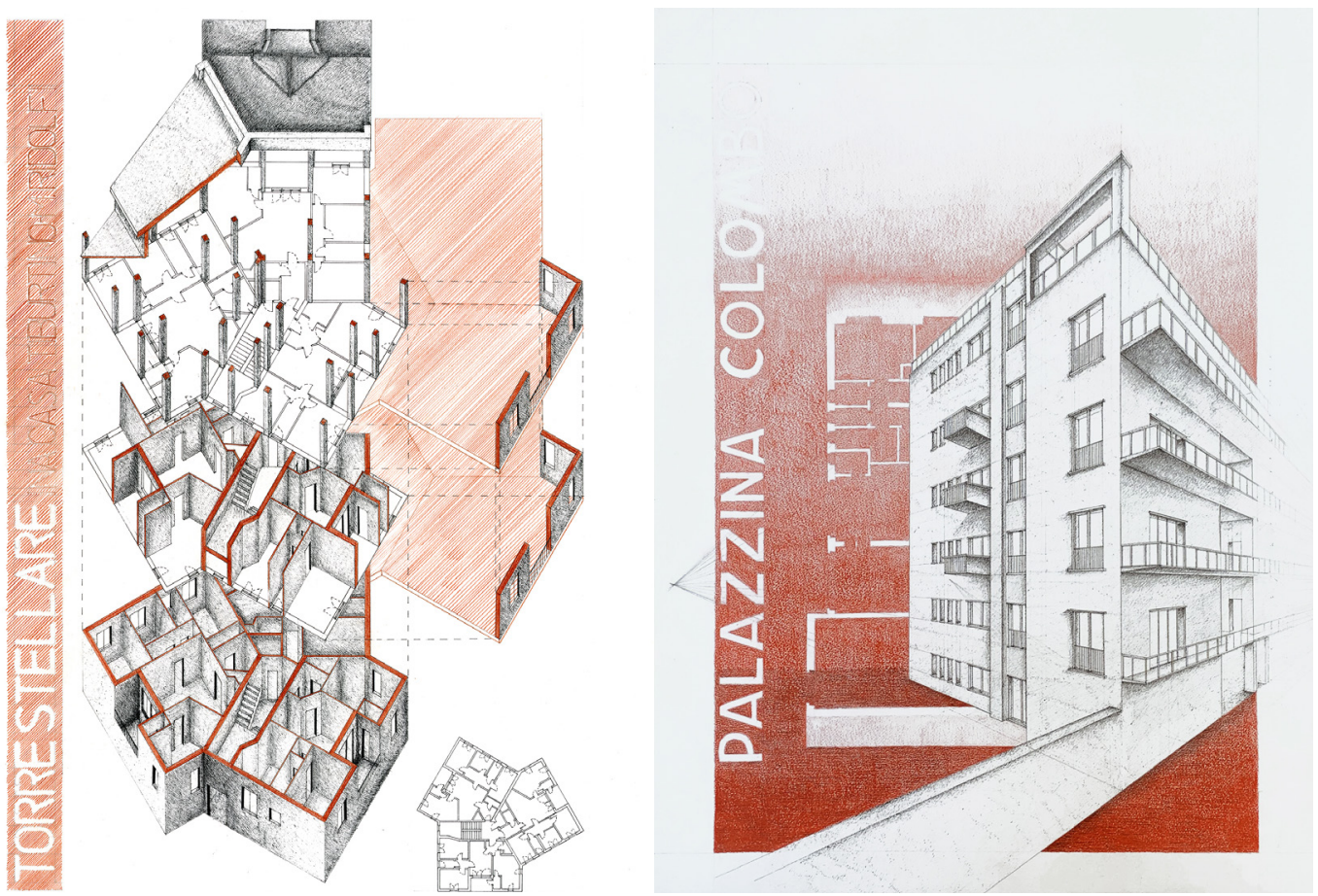

\section{Conclusioni}

Alla fine di questa esperienza alcune domande poste nel testo rimangono ancora aperte: Mantenere un corso a distanza come un corso in presenza è corretto?

Se il Disegno è colmo di articolazione e complessità, allora quale ruolo assume la didattica del Disegno nella formazione dell'architetto se svolta a distanza?

Come stimolare la visione e l'immaginazione, come promuovere la manifestazione del pensiero, come sviluppare le personali capacità espressive in un mondo reale che si fa virtuale? Porre degli effettivi pensieri conclusivi in relazione a una esperienza di tale portata nelle nostre vite e nel nostro ruolo universitario ha poco senso. II particolare periodo che ci troviamo a vivere ha cambiato radicalmente le nostre abitudini, e ancora non sappiamo per quanto durerà. È chiaro che questi argomenti sono e saranno presenti nella nostra esistenza. Non conosciamo a quali altri sviluppi futuri nelle tecnologie e nelle comunicazioni andremo incontro ed è quindi opportuno mantenere la discussione aperta, attiva e dinamica.

\section{Note}

[I] Le teorie che interpretano il processo di apprendimento lo illustrano attraverso delle metafore e dei verbi (trasmettere, costruire e partecipare) che implicano tre differenti spiegazioni del medesimo e delle modalità di lavoro della mente. A tal proposito si veda: Bruner 1999 e Mason 2019. 
Fig. 12. Rappresentazione digitale con disegni realizzati in CAD:Torre realizzati in CAD: Torre
stellare del Piano INA Sasa Tiburtino di Mario Casa Tiburtino di Mario
Ridolfi. La tavola è stata Ridolfi. La tavola è stata realizzata nel corso di
Disegno dell'Architettu$\mathrm{ra}$, svolto in didattica a distanza durante i mesi in lockdown (studentessa Sara Messina).

\section{EDIFICIO A STELLA, INA CASA TIBURTINO Quaroni - Ridolfi 1951-1954}
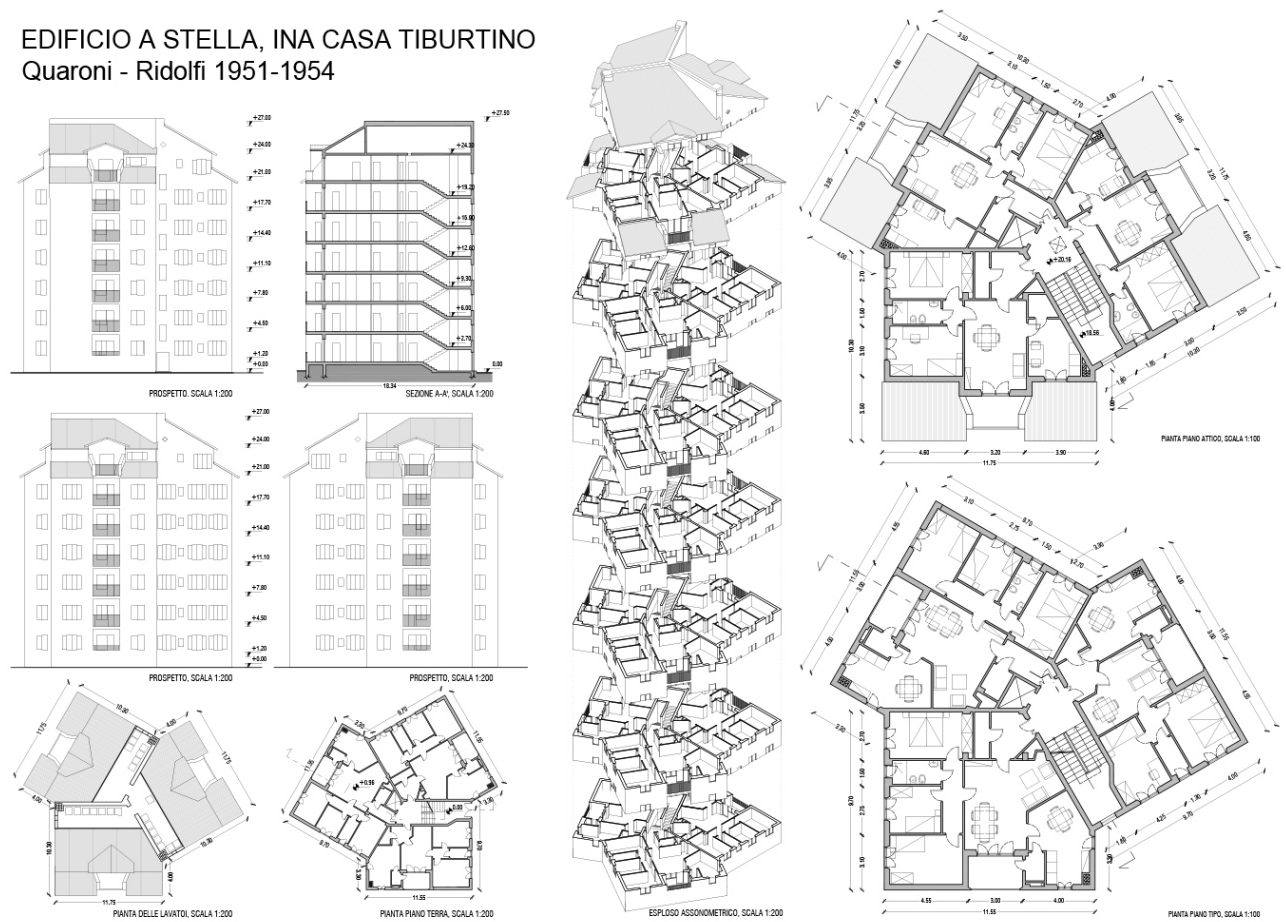

\title{
Riferimenti bibliografici
}

Bruner J. S. (1999). La cultura dell'educazione. Milano: Feltrinelli.

Casale A., Inglese C. (20।3). La forma disegnata. In F. Dal Falco (a cura di). Lezioni di design. Roma: Rdesignpress, pp. I36-I43.

Cervellini F. (2012). Il Disegno officina della forma. Roma: Aracne.

Cervellini F., Partenope R. (a cura di) (1996). Franco Purini. Una lezione sul disegno. Gangemi: Roma.

Giandebiaggi P. (20 I6). Disegno: espressione creativa. In XY digitale, I, pp. 98- I09.

Heidegger M. (1976). Essere e tempo. Milano: Edizioni Longanesi.

Maldonado T. (20।5). Virtuale e reale. Milano: Feltrinelli.

Mason L. (2019). Psicologia dell'apprendimento e dellistruzione. Bologna: Il Mulino.

Quici F. (1995). II disegno come ipertesto progettuale. In XY Dimensioni del disegno, 23-24-25, pp. 55-60.

Seguì de la Riva J. (20 I5). Disegnare, fantasticare, dare forma. In Disegnare. Idee immagini, 5 I, pp. 7-9.

\begin{abstract}
Autori
Maria Grazia Cianci, Università degli Studi Roma Tre, mariagrazia.cianci@uniroma3.it

Daniele Calisi, Università degli Studi RomaTre, daniele d.calisi@gmail.com

Sara Colaceci, Sapienza Università di Roma, sara.colaceci@uniromal .it

Matteo Molinari, Università degli Studi RomaTre, matteo.molinari@uniroma3.it

Per citare questo capitolo: Cianci Maria Grazia, Calisi Daniele, Colaceci Sara, Molinari Matteo (2021). Nuove e vecchie immagini della didattica: reale e virtuale/New and old images of teaching: real and virtual. In Arena A., Arena M., Mediati D., Raffa P. (a cura di). Connettere. Un disegno per annodare e tessere. Linguaggi Distanze Tecnologie. Atti del $42^{\circ}$ Convegno Internazionale dei Docenti delle Discipline della Rappresentazione/Connecting. Drawing for weaving relationship. Languages Distances Technologies. Proceedings of the $42^{\text {th }}$ International Conference of Representation Disciplines Teachers. Milano: FrancoAngeli, pp. 472-489.
\end{abstract}




\title{
New and Old Images of Teaching: Real and Virtual
}

\author{
Maria Grazia Cianci \\ Daniele Calisi \\ Sara Colaceci \\ Matteo Molinari
}

\section{Abstract}

Contemporary societies today find themselves living in a condition never experienced before. They find themselves having to simultaneously apply and interpret material aspects of human life on the one hand, and on the other hand contents and figures that belong to the virtual dimension.

The theme of this paper is to reflect on the issues of drawing, of its teaching in Italian universities, of how it can be carried out adequately in a distance teaching mode and as such three themes are intertwined in the current situation, in which the concepts of real and virtual tend to assume ever more dilated and hybridized boundaries between them.

The Drawing and Drawing involve themes of a wide complexity. In the act of drawing, there is always an experience of searching for one's own signature. This articulation of knowledge is fundamental in the training of architects. Being able to encourage students to discover a personal signity and develop the ability of each one to be aware of the sign are the challenges and objectives to be pursued, as well as providing basic knowledge. At the center of the discussion is not only the result but the unfolding of the gradual process of the Drawing, that is the multiple expressive, cognitive, analytical acts, and in general of developing ideas into shape.

If all this articulation is true, then what role does the teaching of drawing play in the training of the architect if carried out remotely?

Keywords

drawing, teaching, distance learning, language, virtual.

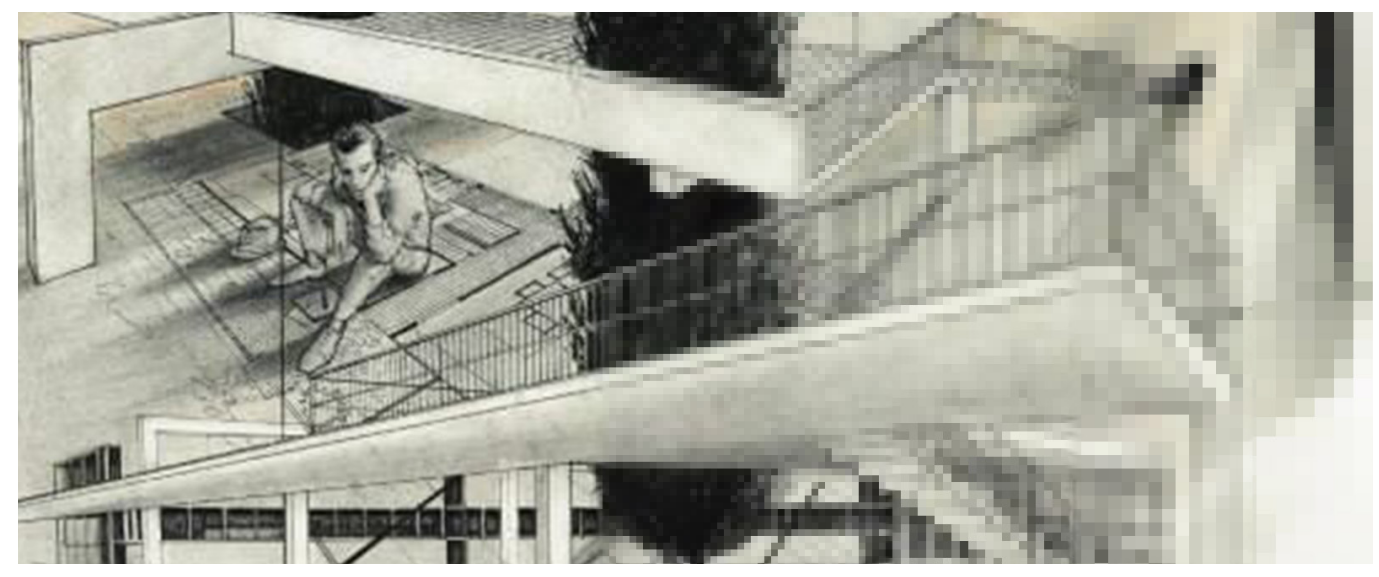




\section{Introduction: the real and the virtual, today}

Contemporary societies today find themselves living in a condition never experienced before. They find themselves having to simultaneously apply and interpret material aspects of human life on the one hand, and on the other hand contents and figures that belong to the virtual dimension.

Man, today more than ever, has found himself catapulted from one moment to the next, without warning, into a completely virtual world, a virtual one that in turn has become real. It is almost natural when one thinks of the virtual to refer to the planes of immaterial reality, to worlds and intangible things, worlds that are opposed to the concrete physicality of the phenomenal world (fig. I).

Tomás Maldonado in his book [Maldonado 20 I 5, p. 23] enters fully into the most interesting, engaging but at the same time most debated and controversial issues in the contemporary cultural panorama: that of advanced technologies, of the virtual world and of the effects they can have on the life of human beings and more generally on the culture of our time.

The simulation of reality offers ideas for rethinking the relationship between reality and its representation and between the virtual and its transposition, but also and above all the relationship between real and virtual and how they can coexist in a new world, in a totally virtual world.

This year we lived in an illusory world, in a world that is no longer parallel but coincides with reality. In it all of us, active operators, have become actors in a virtual space, living it as if it were real.

Fig. I. Film directed by Joseph Kosinski, follow-up to 1982 film Tron,

director Steven Lisberger the first science fiction film to focus on virtual reality. limage taken from: $<$ https://wallpaperaccess. com/tron-legacy> (acce sed 2021, March 20)

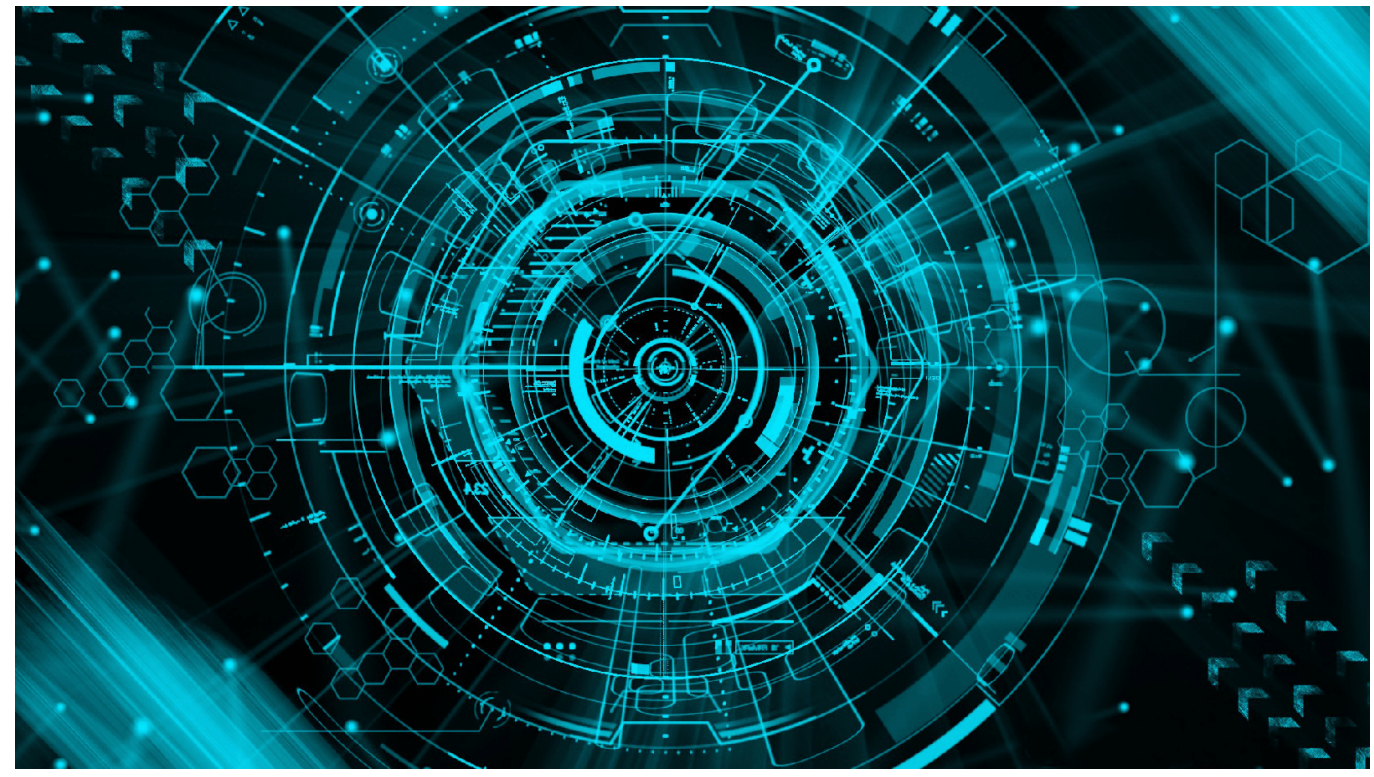

\section{Languages}

The theme of this paper is to reflect on the issues of drawing, of its teaching in Italian universities, of how it can be carried out adequately in a distance teaching mode and as such three themes are intertwined in the current situation, in which the concepts of real and virtual tend to assume ever more dilated and hybridized boundaries between them.

Drawing and Drawing involve themes of a wide complexity. In the act of drawing, an experience of searching for one's own signature is always achieved, which is one of the moments of the indispensable journey in search of oneself.

The drawing is presented and narrated as a creative expression [Giandebiaggi 2016, p. IOI], as the architect's fundamental thought form [Cervellini, Partenope 1996, p. 33], like a 
hypertext [Quici 1995, p. 55]. Its functions are analytical and cognitive, expressive and communicative, exploratory and experimental [Cervellini 20 I2, p. 9], of verification and control (Seguì de la Riva 20 I5, p. 7], educational towards critical ability [Casale, Inglese 20 I3, p. 40]. Drawing is a long and demanding job that proceeds by attempts, by juxtapositions, by second thoughts, by overwriting, by side by side.

This articulation of knowledge is fundamental in the training of architects. Being able to encourage students to discover a personal signity and develop the ability of each one to be aware of the sign are the challenges and objectives to be pursued, as well as providing basic knowledge. At the center of the discussion is not only the result, but the unfolding of the gradual process of Drawing, that is, the multiple expressive, cognitive, analytical acts, and in general, of putting ideas into shape.

If all this articulation is true, then what role does the teaching of drawing play in the training of the architect if carried out remotely? How to stimulate vision and imagination, how to promote the manifestation of thought, how to develop personal expressive skills in a real world that becomes virtual?

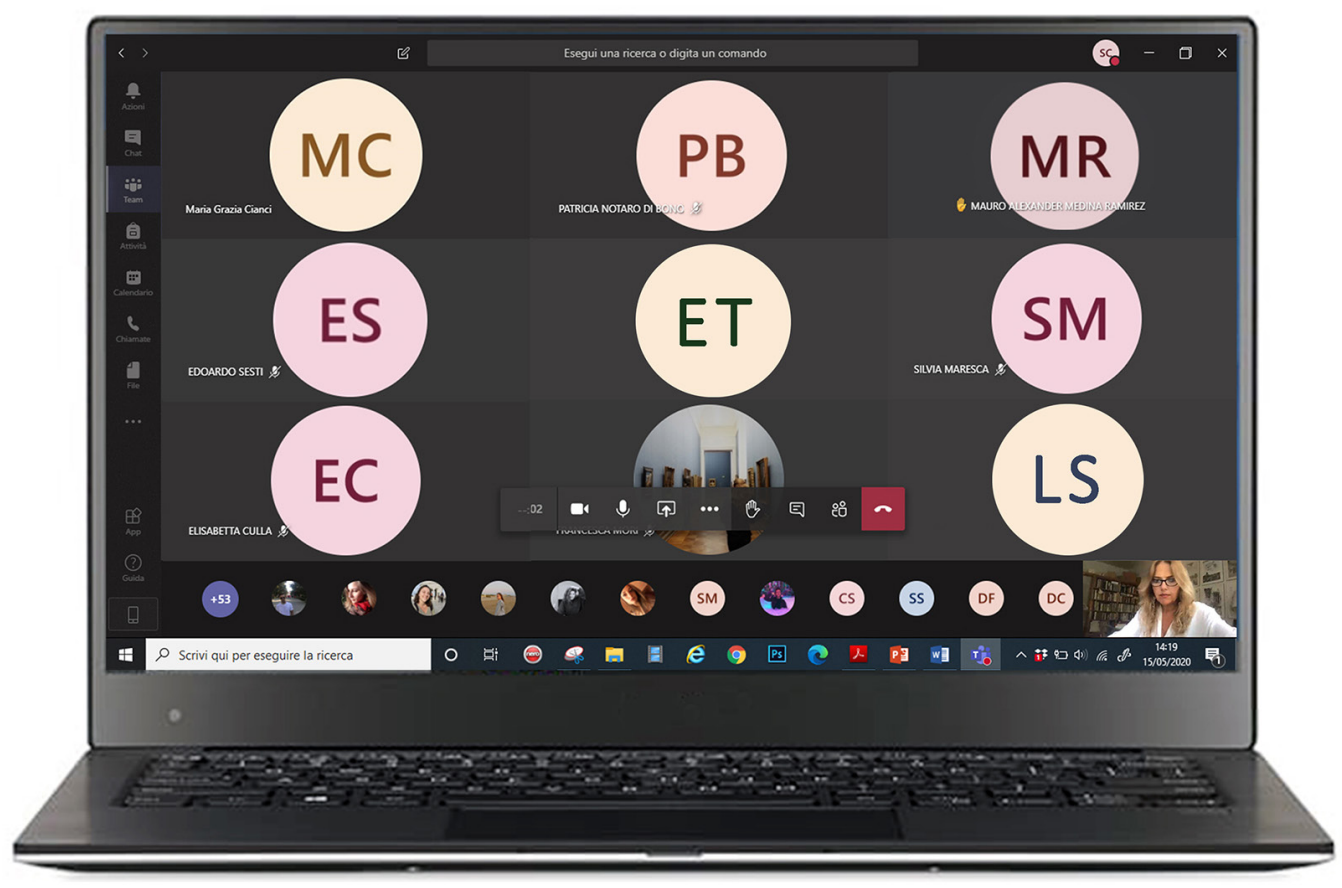

Until March 2020 the teaching was carried out and started through tangible and concrete experiential events which, although simple and basic, needed a physicality: to discover the tools, try the techniques, explore the places of the city in a participatory relationship between the teacher and learner.The tactile properties of the physical and architectural materials involved in it concur in the Drawing, which it is inadmissible to exclude.

With distance learning it is necessary to avoid the risk and the drift that it results in a learning model that educational psychology indicates as a metaphor for the transmission of knowledge, i.e. constituted by the teacher (sender) who transfers knowledge to the learner (recipient) [I]. In this model, knowledge is considered something predefined, the mind is considered a container and only a listening is done by the student, without a transformation during the transfer of knowledge.

The absence of tangibility and, more generally, the lack of human relationships that occur in the DAD (fig. 2) lead to the success of a model that favors individual learning and that 

draw at their table, in the virtual classroom or their learning lesson. cancels those fundamental values of construction and participation in a training course. Drawing, or rather the teaching of it, implies knowledge and know-how, dialectics and exercise, theory and practice, therefore it is necessary to avoid that it is confined to restrictive learning models that do not belong to it and that do not are inherent in its nature.

For these reasons, during the Architectural Drawing course we tried to solicit the operational dimension of the Design. The lack of physical interaction prevented that fundamental didactic moment in which the teacher 'puts the pencil on the paper' to correct errors, to experiment with techniques or to simply show the value and uniqueness of the graphic sign. However, we tried to make up for this lack through some precautions. For example, the 'drawing in the classroom' was maintained by the students (fig. 3), but also by the teachers and assistants, with the aim of keeping the link with the discipline alive and constant.

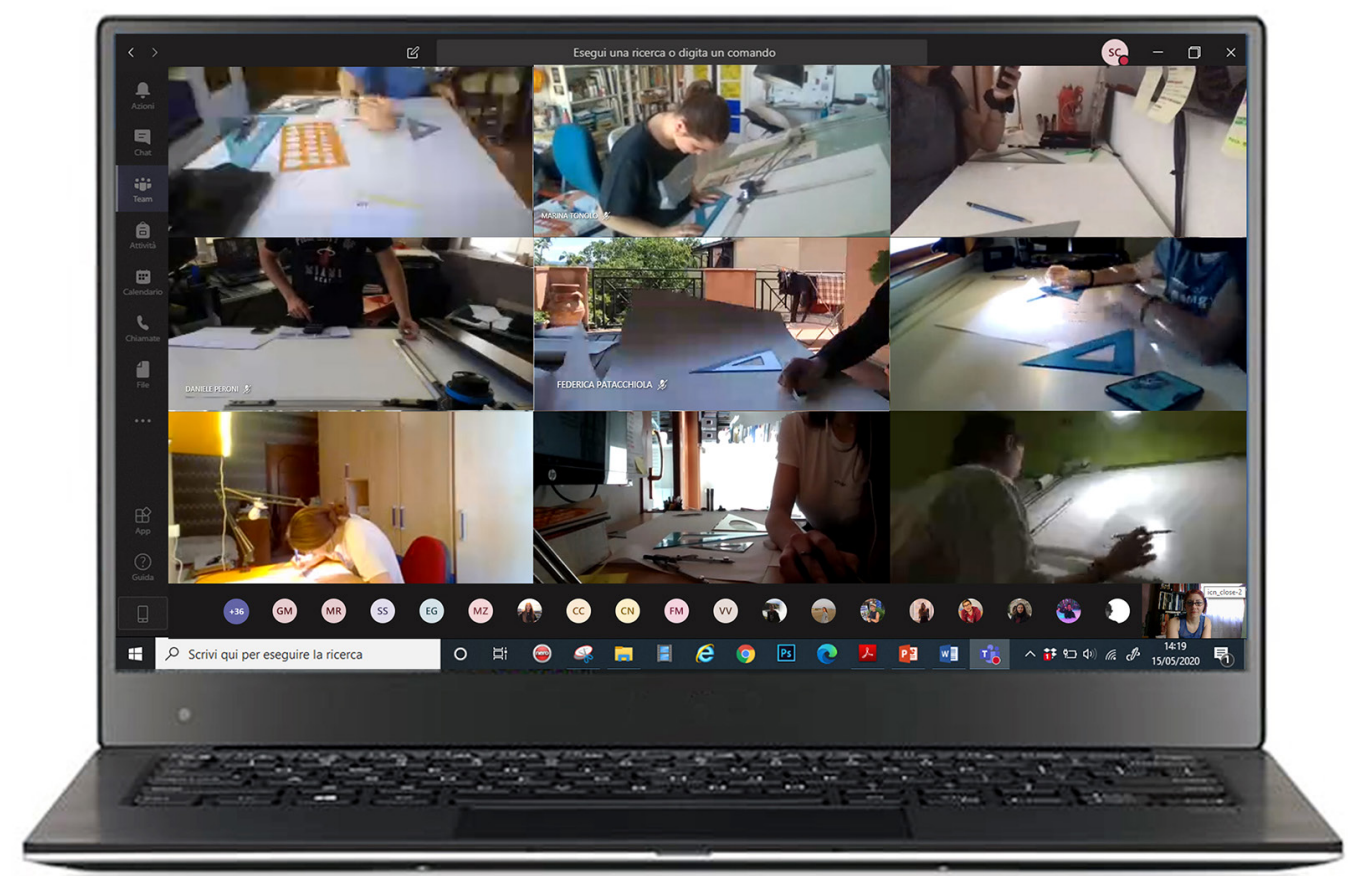

\section{Technologies}

In the last year, technology and digital have taken on a new role in the field of communication, teaching and dissemination of architectural design. If before they were seen as the tool that would lead to the end of analog drawing, they have now become the only means through which it is possible to teach it. For centuries, the term digit (from the Latin digitus) meant finger, but now its adjectival form, digital, refers to the data; this transformation follows perfectly the needs of today.

The virtualization of classrooms has changed not only the way people relate, but also the perception of time itself. 2 I st century society is hyper-connected, everything can be done through a computer, a smartphone, a tablet, and everything has to be instantaneous.

Man's lifestyle has undergone an acceleration in which the same social relationships are easier to establish, but at the same time more fragile. This digitization has always been a part of a person's life, where the physicality of relationships and the ability to interact with the surrounding world balanced this continuous need for hyper-connection. A non-perfect balance, therefore, between the acceleration given by digital and the natural flow of time 
Fig. 4. Frontal lesson during which drawings were shared aimed at explaining the architectural project.

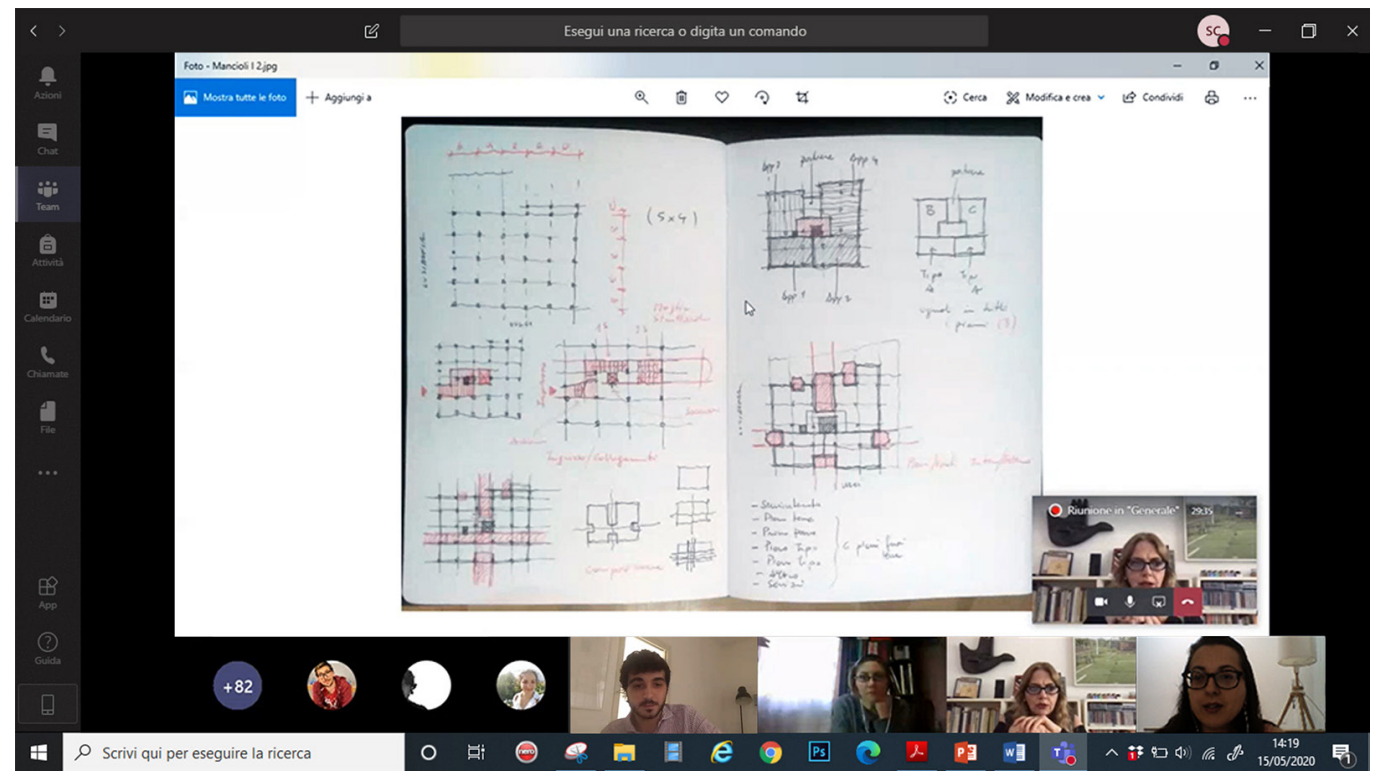

in human relationships. In the society of hyper-connection and hyper-complexity, it is necessary to alternate speed and slowness, since man needs both. University teaching had to understand and know how to use technology in a few months to be able to convey the same concepts. The teaching of Architectural Drawing is based on an exchange not only of concepts but of movements, of techniques that can be learned through direct and practical teaching, through which a relationship is established between teacher and student. For this reason, the Architectural Design course had to assimilate digital platforms to try to transmit the same teachings at a distance.

Technology has allowed the sharing of the drawings live during the lesson to comment on them and to correct them (fig. 4). It also allowed for didactic tests since the documents, delivered and uploaded to the platform, were subsequently corrected by the teaching staff through the graphic tablet.

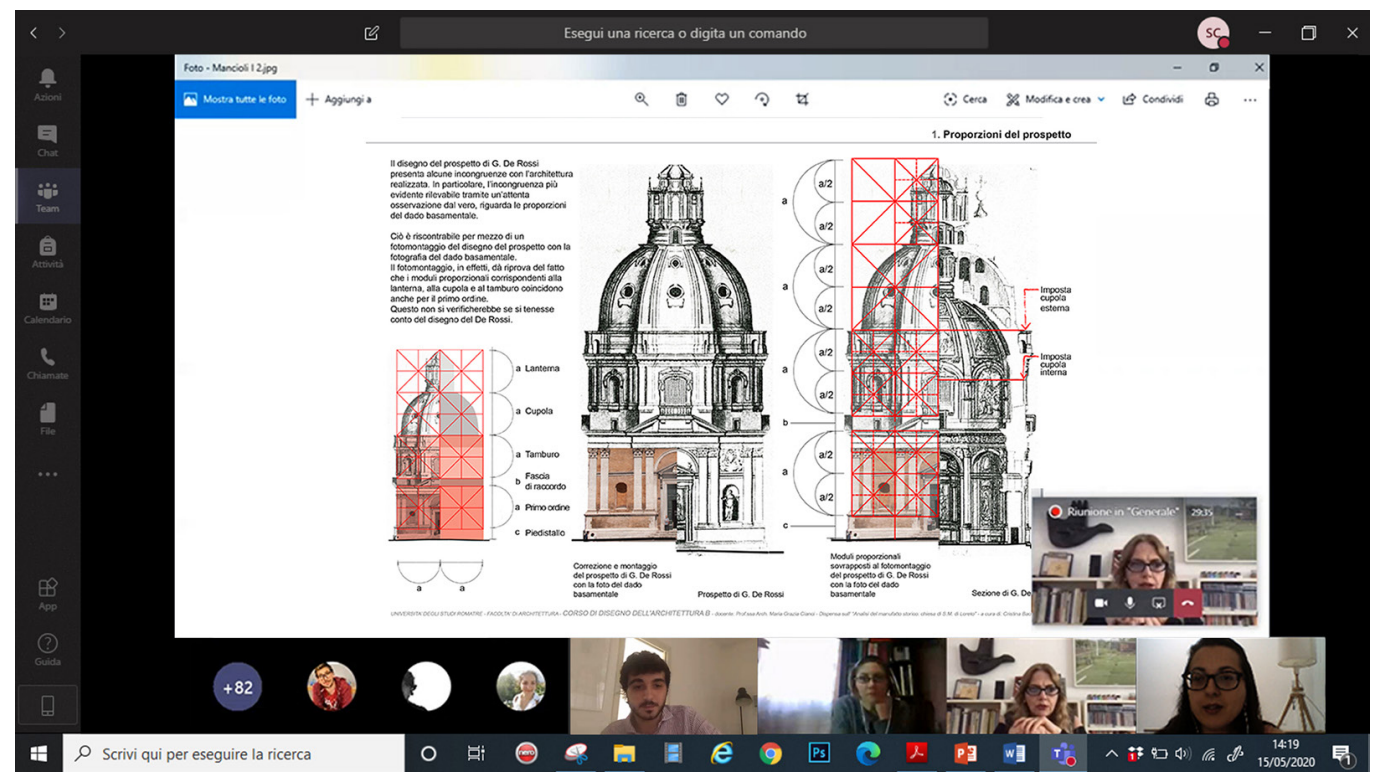

Fig. 5. Frontal lesson during which drawings and digital elaborations were shared aimed at explaining classical architecture. 
The techniques of representation were shown through recorded videos, like tutorials, in which the student can see the hand that defines the signs, the backgrounds, the textures, the color.

The platforms (Teams, elearning site, blog, fb) made it possible to implement the frontal lessons (figs. 5, 6), and that set of organization and management of the course consisting of notices, handouts, tasks to be carried out with deadlines weekly, in addition to the sharing of teaching material.

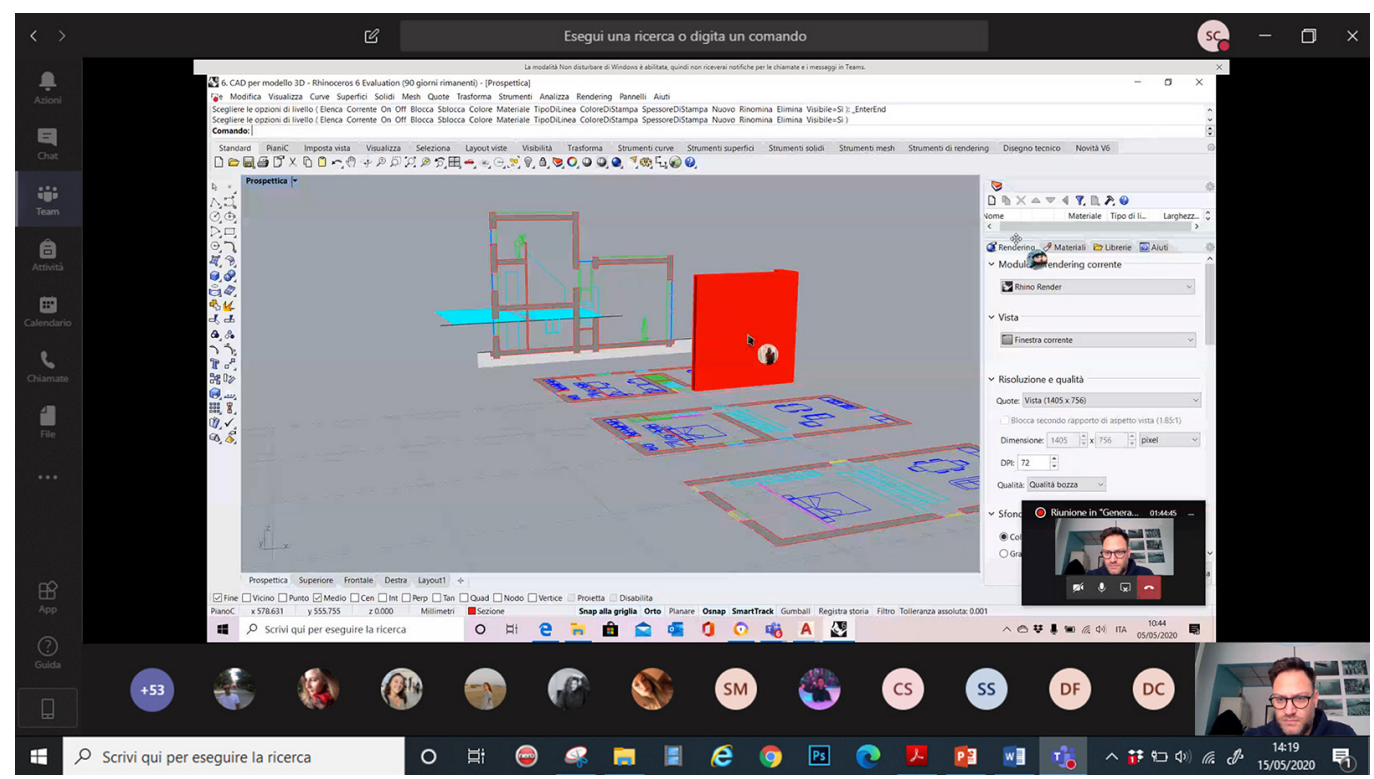

\section{Distances: relationships between time, sharing and connections}

A substantial difference between the real and the virtual is the distance under different meanings: in terms of the physical distance that divides us from a goal, of social distance or perceptual distance.

In the same myth of Plato's cave, the perception of shadows (the virtual) is immediate for man who is unaware not only of what is true, but also of the effective distance of reality. We had to learn to exclude distances from our life, forced to re-read a consolidated everyday life made up of distances to travel to reach workplaces, friends or relatives, social or physical contacts.

And if the obligation to remain still has distanced us from our places and habitual realities, the virtual has given us infinite possibilities of connection [Heidegger 1976, p. 28].

However, limiting oneself to the geometric distance alone does not exhaust the description of our relationships with people and things in which cultural and ideological conditioning also linked to the subjective personality enter. When Heidegger deals with Being-there as an existential structure, he addresses the theme of care, of being in a context or space. Man has an exclusive relationship with the world that inhabits him but at the same time he takes care of it, cares about it and is interested in it. This concept goes beyond dimensional spatiality but is connected to the relative existential situation. In the last year, detachment has allowed us to make physical distances disappear, and has allowed us to take care of our things in different ways and far from our habitual ways of being.

In this abnormality, an attempt was made to conduct a distance course maintaining the same objectives as a face-to-face course. The topics have been preserved, namely the architectur- 
Fig. 7. Extempore I on the architectural project: Mario Ridolfi's House of Witches. The table was in the Architectural Design course, carried out in remote teaching during the months in lockdown (student Chiara Tucci).

Fig. 8. Extempore 2 on the understanding of classical architecture: the Church of Santa Maria di Loreto. The table was created during the Architectural Drawing course, carried out in remote teaching during the months in lockdown (student Flavia Manciocchi).

Fig. 9. Extempore 2 on the understanding of classical architecture: the Church of Santa Maria di Loreto. The table was created during the Architectural Drawing course, carried out in remote teaching during the months in lockdown (student: Marco Peperon Romano).
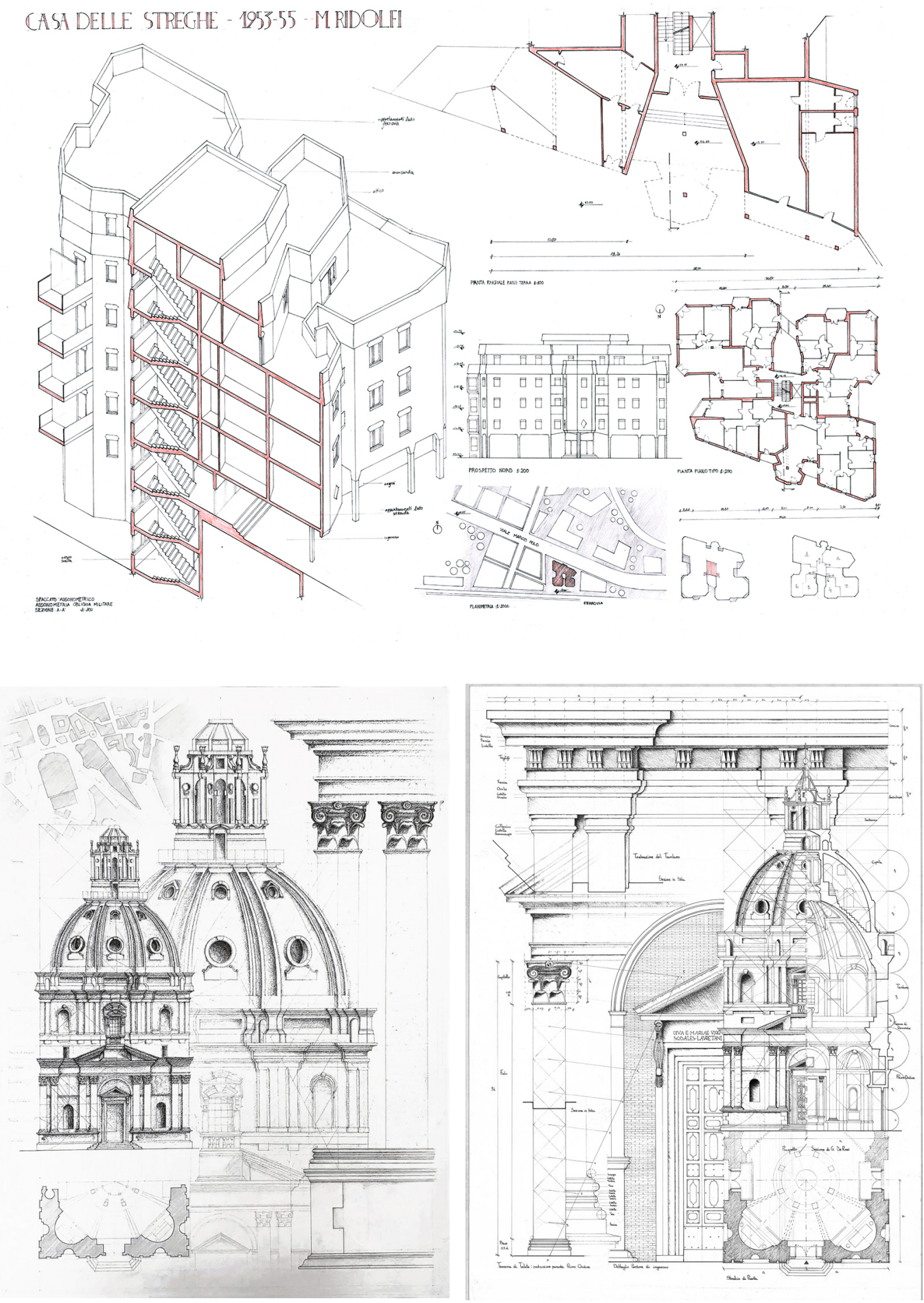
al project, the understanding of classical architecture, the architecture manifesto (figs. 7-9) developed with analogue drawings and digital representation (figs. 10-12), while detection (visual and direct) has been removed. The extempore, the tables and the notebook have been preserved, in order to provide the same didactic training.

Fig. 10. Extempore 3 on the architectura manifesto: Star tower of the INA Plan Tiburtino House by Mario Ridolfi. The table was created during the Architectural Drawing course, carried renting during the months in ung nglisa).

Fig. I I. Extempore 3 on the architectura manifesto: Palazzina

Colombo by Mario Ridofi. The table was created during the Architectural Drawing course, carried out in remote teaching during the months in

lockdown (student Flavia

Manciocchi).
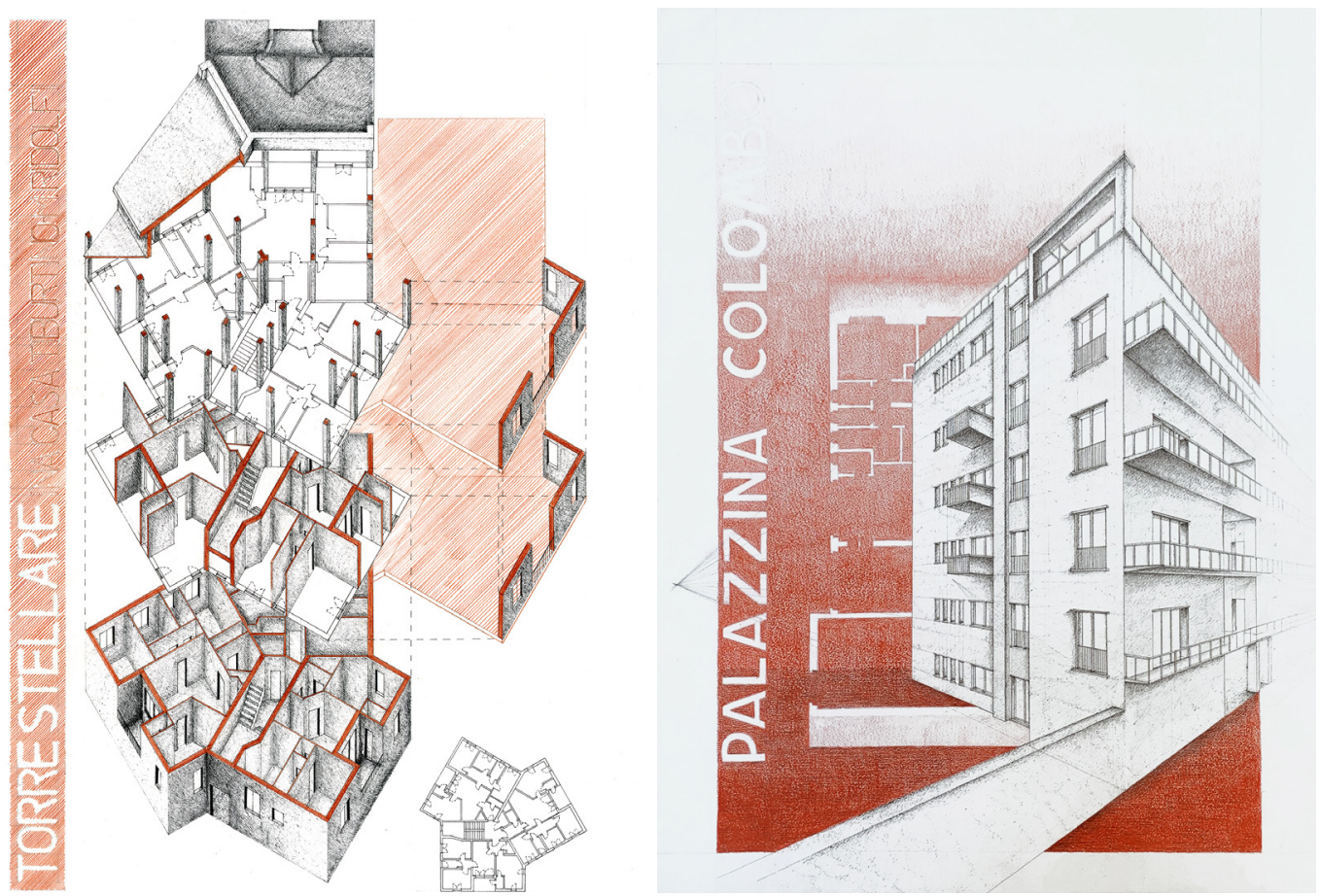

\section{Conclusions}

At the end of this experience some questions posed in the text still remain open: Is maintaining a distance course such as a face-to-face course, correct? If drawing is full of articulation and complexity, then what role does the teaching of drawing play in the training of the architect if carried out remotely?

How to stimulate vision and imagination, how to promote the manifestation of thought, how to develop personal expressive skills in a real world that becomes virtual?

Placing actual concluding thoughts in relation to an experience of this magnitude in our lives and in our university, role makes little sense. These topics are and will be present in our existence, so it is appropriate to continue to discuss them.

\section{Notes}

[I] Learning process theories use metaphors and verbs (transmitting, constructing and participating) which involve three different explanations of how the mind works. See: Bruner 1999 and Mason L. 2019. 
Fig. 12. Digital representation in CAD:Torre stellare of the Piano INA Casa Tiburtino by Mario Ridolfi. The table was created during the Architectural Drawing course, carried out in remote teaching during the months in lockdown (student Sara Messina).

\section{EDIFICIO A STELLA, INA CASA TIBURTINO Quaroni - Ridolfi 1951-1954}
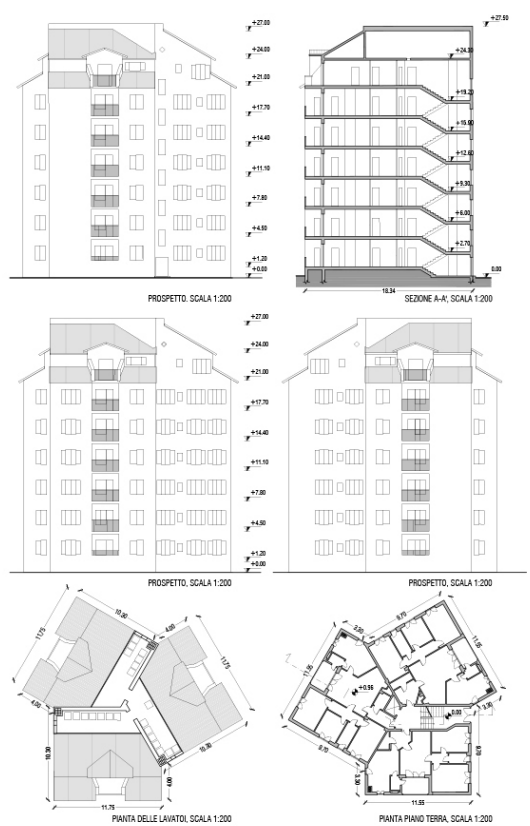
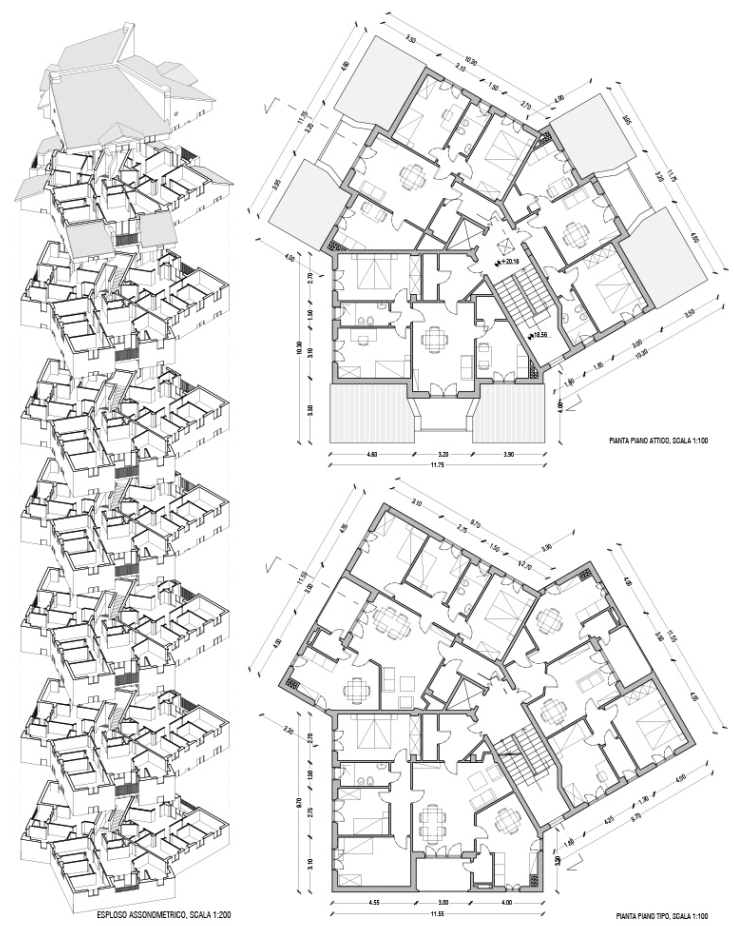

\section{References}

Bruner J. S. (1999). La cultura dell'educazione. Milano: Feltrinelli.

Casale A., Inglese C. (20I3). La forma disegnata. In F. Dal Falco (a cura di). Lezioni di design. Roma: Rdesignpress, pp. I36-I43.

Cervellini F. (20I2). II Disegno officina della forma. Roma: Aracne.

Cervellini F., Partenope R. (a cura di) (1996). Franco Purini. Una lezione sul disegno. Gangemi: Roma.

Giandebiaggi P. (20 I6). Disegno: espressione creativa. In XY digitale, I, pp. 98- 109.

Heidegger M. (1976). Essere e tempo. Milano: Edizioni Longanesi.

Maldonado T. (20I5). Virtuale e reale. Milano: Feltrinelli.

Mason L. (2019). Psicologia dell'apprendimento e dellistruzione. Bologna: Il Mulino.

Quici F. (1995). II disegno come ipertesto progettuale. In XY Dimensioni del disegno, 23-24-25, pp. 55-60.

Seguì de la Riva J. (20 I5). Disegnare, fantasticare, dare forma. In Disegnare. Idee immagini, 5 I, pp. 7-9.

\section{Authors}

Maria Grazia Cianci, Università degli Studi Roma Tre, mariagrazia.cianci@uniroma3.it

Daniele Calisi, Università degli Studi Roma Tre, daniele d.calisi@gmail.com

Sara Colaceci, Sapienza Università di Roma, sara.colaceci@uniromal .it

Matteo Molinari, Università degli Studi RomaTre, matteo.molinari@uniroma3.it

To cite this chapter. Cianci Maria Grazia, Calisi Daniele, Colaceci Sara, Molinari Matteo (202I). Nuove e vecchie immagini della didattica: reale e virtuale/New and old images of teaching: real and virtual. In Arena A., Arena M., Mediati D., Raffa P. (a cura di). Connettere. Un disegno per annodare e tessere. Linguaggi Distanze Tecnologie. Atti del $42^{\circ}$ Convegno Internazionale dei Docenti delle Discipline della Rappresentazione/Connecting. Drawing for weaving relationship. Languages Distances Technologies. Proceedings of the $42^{\text {th }}$ International Conference of Representation Disciplines Teachers. Milano: FrancoAngeli, pp. 472-489. 